\title{
The effects of low-dose methylprednisolone as adjuvant therapy for hemophilia A patients with factor VIII inhibitors
}

\author{
Sri Marwanta ${ }^{*}$ (D), Soetrisno Soetrisno ${ }^{1}$ (D), Bambang Purwanto ${ }^{1}$ (D), Brian Wasita ${ }^{2}$ (D), Tonang Dwi Ardyanto (D), $^{\text {D }}$ \\ Faizal Muhammad ${ }^{4}$ (D), Eti Poncorini Pamungkasari ${ }^{5}$ (D), Dono Indarto ${ }^{6}$ (D), Eillien Ramadhani Fauzi ${ }^{4}$ (D) \\ ${ }^{1}$ Doctoral Program of Medical Sciences Department, Faculty of Medicine, Sebelas Maret University, Surakarta, Indonesia. \\ ${ }^{2}$ Pathology Anatomy Department, Dr. Moewardi General Hospital, Sebelas Maret University, Surakarta, Indonesia. \\ ${ }^{3}$ Clinical Pathology Department, UNS Teaching Hospital, Faculty of Medicine, Sebelas Maret University, Surakarta, Indonesia. \\ ${ }^{4}$ Internal Medicine Department, UNS Teaching Hospital, Faculty of Medicine, Sebelas Maret University, Surakarta, Indonesia. \\ ${ }^{5}$ Public Health Department, Faculty of Medicine, Sebelas Maret University, Surakarta, Indonesia. \\ ${ }^{6}$ Biomedics and Physiology Department, Faculty of Medicine, Sebelas Maret University, Surakarta, Indonesia.
}

\begin{tabular}{l}
\hline ARTICLE INFO \\
\hline Received on: 03/07/2021 \\
Accepted on: 05/12/2021 \\
Available Online: 05/12/2021 \\
\hline Key words: \\
Adjuvant therapy, \\
factor VIII, factor VIII \\
inhibitors, hemophilia A, \\
immunosuppressive therapy, \\
methylprednisolone.
\end{tabular}

\begin{abstract}
Hemophilia A is an inherited bleeding disorder caused by factor VIII (FVIII) deficiency. In most minor-to-moderate bleeding events, FVIII concentrates therapy can result in significant lifesaving. However, chronic FVIII concentrates therapy can cause FVIII inhibitors synthesis and replacement therapy to be inefficacious. Immunosuppressive therapy can suppress FVIII inhibitors synthesis and make FVIII concentrates therapy more responsive. This study aims to determine the effects of low-dose methylprednisolone (MP) on acquired FVIII inhibitors. A randomized clinical trial was conducted on 11 hemophilia A male patients with a high level of FVIII inhibitors. This pretest-posttest study design consists of an intervention group (six patients) who received $1 \mathrm{mg} /$ body weight/day MP and a control group (five patients) who received a $100 \mathrm{mg} /$ day sugar pill placebo for 6 weeks. Statistical analysis used the independent $t$-test and paired $t$-test. The results showed significant FVIII inhibitors rising in pretest-posttest mean comparison of both the intervention group $(p=0.001)$ and control group $(p=0.001)$. Further results showed the intergroups' pretest mean comparison $(p=0.976)$ and intergroups' posttest mean comparison $(p=0.034)$. It can be concluded that lowdose MP significantly suppresses the FVIII inhibitors synthesis pace within 6 weeks instead of inhibiting the FVIII inhibitors synthesis.
\end{abstract}

\section{INTRODUCTION}

Hemophilia A is a congenital hemorrhagic disorder caused by factor VIII (FVIII) genetic abnormality (Castaman and Matino, 2019). It is a disorder that is complex to treat. Hemophilia A accounts for about $80 \%$ of approximately 400,000 hemophilia cases worldwide (Machin et al., 2018). Meanwhile, only 25\% of hemophilia A cases receive adequate therapy (Kadhim et al., 2019). Arthropathy and cerebrovascular complications remain

*Corresponding Author

Sri Marwanta, Doctoral Program of Medical Sciences, Faculty of Medicine, Sebelas Maret University, Surakarta, Indonesia.

E-mail: marwantasppdmkes@student.uns.ac.id barriers to normal daily activities performance among hemophilia A patients (Baek et al., 2020). The current routine therapy to a treat bleeding event depends on replacement therapy of clotting factor concentrates since childhood. Meanwhile, chronic factor concentrates therapy causes the development of FVIII inhibitors (Santagostino et al., 2018). Studies have showed that 3\%-13\% of mild and most cases of moderate-to-severe hemophilia A patients developed FVIII inhibitors (Yamanouchi et al., 2018). This neutralizing antibody certainly causes inadequate replacement therapy and poor medical outcomes (Walsh et al., 2016).

Treatment of patients with FVIII inhibitors including porcine FVIII activated prothrombin complex concentrate and activated recombinant factor VII, desensitization, immune tolerance induction, and a monoclonal antibody that bridge factor IXa and factor X (Meeks and Batsuli, 2016). However, 
the therapies are difficult to obtain and expensive in the limited healthcare resources of low-income countries. Some studies recommend that steroid drugs may be useful as adjuvant therapy for hemophilia A patients with a higher titer of FVIII inhibitors (Cacciotti et al., 2021).

Methylprednisolone (MP) is a prednisone-derived drug with potent anti-inflammatory and immunosuppressive effects even in low doses. MP also has minimal side effects of water retention, sodium retention, weight gain, and gastric irritation in long-term therapy compared to other steroid derivatives (Permana et al., 2019). It is a cost-effective drug and is widely available in every healthcare setting. Hence, this study aims to investigate the effect of low-dose MP on hemophilia A patients with FVIII inhibitors.

\section{MATERIALS AND METHODS}

\section{Hemophilia A patients and study setting}

This 6-week randomized pretest-posttest clinical trial with a control group design was conducted from September 2020 to March 2021 at the Hematology Polyclinic of Dr. Moewardi General Hospital, Surakarta, Indonesia. The participant inclusion criteria included male patients older than 18 years with a history of FVIII concentrates therapy for more than 9 exposure days (Witmer and Young, 2013). The exclusion criteria are other bleeding disorders comorbidities, other system organs' comorbidities, and being currently on steroid drug therapy. During the 3 months of the simple random sampling period, only 11 hemophilia A patients met the study criteria. Then, the participants were randomly divided into a intervention group $(n=6)$ and a control group $(n=5)$.

\section{Variables and interventions}

FVIII inhibitors were analyzed using the enzyme-linked immunosorbent assay (ELISA) method. The data were measured in $\mathrm{ng} / \mathrm{ml}$. In the pretest period, the baseline or pretest clinical parameter data were also measured. They included body weight, fasting blood glucose (FBS), hemoglobin (Hb), white blood cells (WBC), platelet, prothrombin time (PT), and activated partial thromboplastin time (APTT). The FVIII inhibitors and clinical parameter data were tested in both pretest and posttest studies.

The interventions included $1 \mathrm{mg} /$ body weight/day MP for the intervention group and a $100 \mathrm{mg} /$ day sugar pill placebo for the control group. The intervention duration was 6 weeks. The patients were educated not to carry out high-risk activities during the intervention period according to the Hemophilia Activities List. The patients were not allowed to consume vitamin $\mathrm{E}$ and certain herbal supplements to prevent the platelets from clumping. Aspirin and nonsteroidal anti-inflammatory drugs were prohibited because they may cause bleeding risk.

\section{Data collection}

The FVIII inhibitors and laboratory parameters of FBS, $\mathrm{HB}, \mathrm{WBC}$, platelet, PT, and APTT were obtained from participants' vein blood. The BIOENZY Human Coagulation FVIII ELISA kits were used to analyze the FVIII inhibitors' titers. It has a sensitivity of $0.28 \mathrm{ng} / \mathrm{ml}$ and a standard curve range of $0.5-150 \mathrm{ng} / \mathrm{ml}$. Based on the participant group, either $1 \mathrm{mg} /$ body weight MP or a 100 mg sugar pill was prescribed for as many as 42 drugs for 6 weeks.

\section{Statistical analysis}

The paired $t$-test was used to analyze the pretest-posttest FVIII inhibitors mean comparison of the intervention group and control group. The independent $t$-test was used to analyze FVIII inhibitors mean comparison of intergroups' pretest and posttest (Fig. 1). The statistical analyses were conducted using Statistical Package for the Social Sciences 22 statistical software for Windows.

\section{Ethical approval}

This study was approved by the Health Research Ethics Committee of Dr. Moewardi General Hospital, No. 1.069/ $\mathrm{XI} / \mathrm{HREC} / 2019$. The study was also conducted following the Helsinki Declaration. All the participants received a study protocol explanation and gave written informed consent. The ethical approval is available for review by the Editor-in-Chief of this journal.

\section{Results and Discussion}

The clinical parameters' baseline or pretest and posttest data were checked to ensure that the MP or placebo administration did not significantly $(p>0.05)$ affect the clinical and laboratory conditions of the participants (Table 1). MP has a wide range of physiologic effects, including endocrine, immunologic, and hematologic disorders (Yang et al., 2020). The only significant difference between the intervention and control groups in the posttest APTT parameters $(p=0.039)$ indicated that MP affected the intrinsic pathway of blood coagulation. FVIII inhibitors or autoantibodies synthesis in hemophilia A patients is a multifactorial process and involves cytokines and immune regulatory molecules (Tieu et al., 2020). This T-cell-mediated hypersensitivity is mediated by inflammatory cytokines like interleukin-1, interleukin-6, and tumor necrosis factor-alpha. The administration of MP can inhibit these inflammatory cascades, which significantly shortened the APTT duration in the intervention group (Ebrahimi et al., 2016).

The intervention group continued to undergo a significant increase in FVIII inhibitors levels $(p=0.001)$ within 6 weeks, as did the control group (Table 2). These indicated that administration of MP neither inhibited nor stopped the synthesis of FVIII inhibitors. The FVIII antibodies' formation requires the FVIII endocytosis process through the role of antigen-presenting cells (Astermark, 2015). Human leukocyte antigen class II molecules then present the endocytosis results to the surface of the cluster of differentiation $4+(\mathrm{CD} 4+) \mathrm{T}$ cells. Moreover, T-regulatory cells (Tregs) have an inhibition role in the FVIII antibody formation process (Khalilian et al., 2020). Tregs inhibit the antigen-specific B-cell differentiation into memory B-cells and CD4+ activation by interleukin-10 (Delignat et al., 2019). Thus, there will be a potentiation effect to inhibit FVIII antibodies synthesis by an immunosuppressive drug. However, the relationship between FVIII inhibitors formation in hemophilia and Tregs function is still inconclusive. It is believed to be due to $H M O X-1$ gene polymorphism in hemophilia patients (Repessé et al., 2013).

Six weeks after MP and placebo administration, there was a significant difference $(p=0.034)$ in the mean levels of FVIII inhibitors between the intervention and control groups. The APPT posttest laboratory parameters between the intervention and the control groups are also significant $(p=0.039)$ (Table 1). A study also showed that prednisone adjuvant therapy alone could control bleeding episodes in hemophilia patients with FVIII inhibitors. Moreover, the study recommended the use of prednisone-cyclophosphamide as 


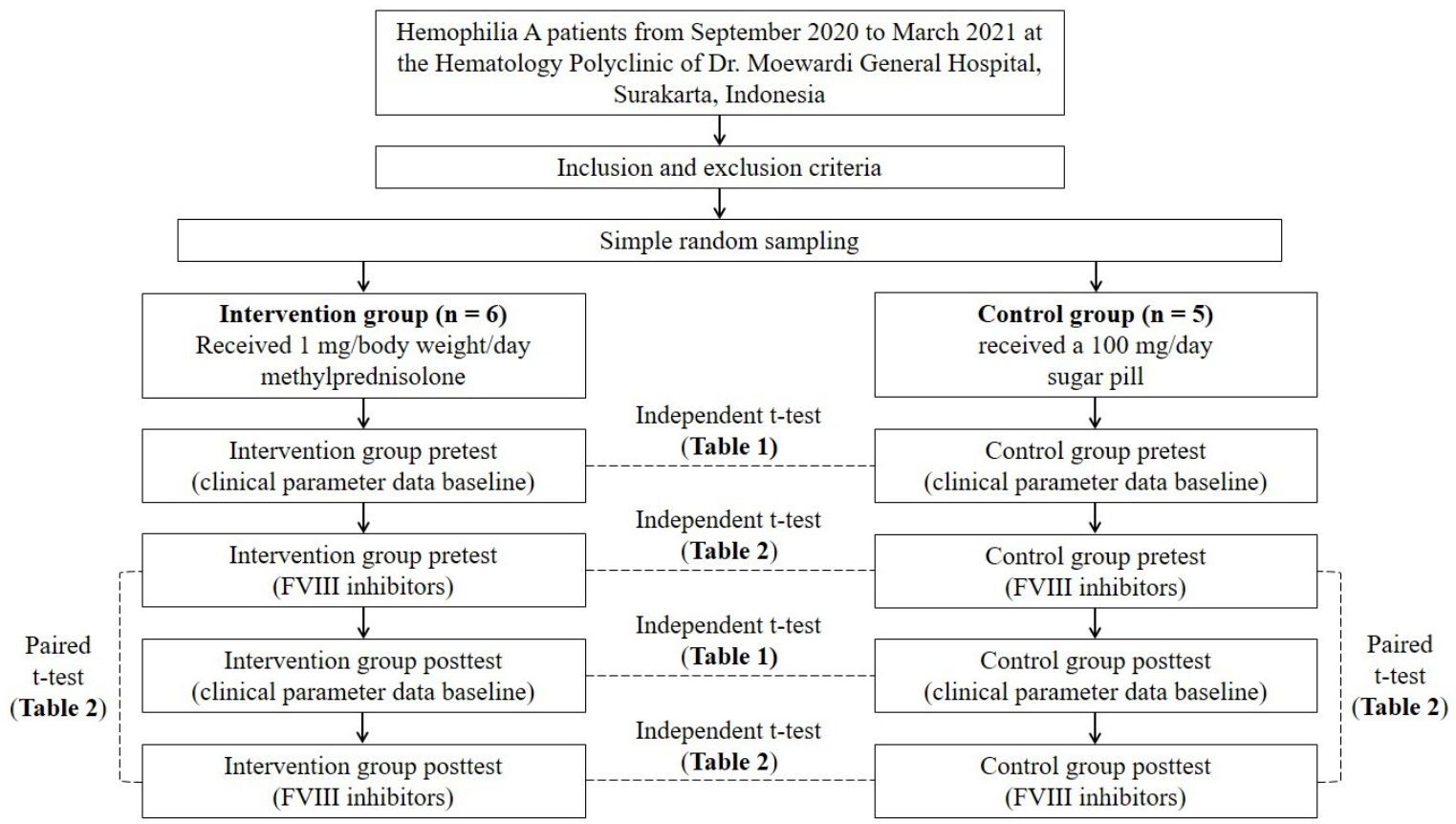

Figure 1. Graphical flow chart diagram of the study.

Table 1. Clinical parameter data baseline or pretest and posttest of both control and intervention groups.

\begin{tabular}{|c|c|c|c|c|c|}
\hline \multirow{2}{*}{ Clinical parameter data } & \multicolumn{2}{|c|}{ Control $(n=5)$} & \multicolumn{2}{|c|}{ Intervention $(n=6)$} & \multirow{2}{*}{$p$-value } \\
\hline & Mean & SD & Mean & SD & \\
\hline \multicolumn{6}{|l|}{ Pretest } \\
\hline Body weight (kg) & 51.0 & 5.8 & 60.2 & 12.0 & 0.155 \\
\hline FBS (mg/dl) & 112.8 & 13.1 & 107.8 & 11.9 & 0.527 \\
\hline $\mathrm{Hb}(\mathrm{g} / \mathrm{dl})$ & 11.9 & 1.4 & 12.1 & 1.6 & 0.864 \\
\hline $\operatorname{WBC}\left(10^{3} / \mathrm{dl}\right)$ & 6.4 & 1.5 & 6.2 & 1.7 & 0.833 \\
\hline Platelet $\left(10^{3} / \mathrm{dl}\right)$ & 324.0 & 104.1 & 297.3 & 122.0 & 0.709 \\
\hline PT (s) & 11.6 & 2.1 & 12.3 & 2.1 & 0.573 \\
\hline APTT (s) & 49.4 & 7.4 & 50.7 & 5.6 & 0.754 \\
\hline \multicolumn{6}{|l|}{ Posttest } \\
\hline Body weight $(\mathrm{kg})$ & 51.0 & 5.4 & 60.3 & 12.0 & 0.161 \\
\hline FBS (mg/dl) & 118.6 & 10.4 & 112.3 & 10.9 & 0.358 \\
\hline $\mathrm{Hb}(\mathrm{g} / \mathrm{dl})$ & 12.1 & 1.3 & 12.5 & 1.5 & 0.640 \\
\hline WBC $\left(10^{3} / \mathrm{dl}\right)$ & 6.1 & 1.5 & 5.9 & 1.7 & 0.812 \\
\hline Platelet $\left(10^{3} / \mathrm{dl}\right)$ & 308.4 & 88.1 & 308.5 & 127.7 & 0.999 \\
\hline PT (seconds) & 11.6 & 1.5 & 11.8 & 1.8 & 0.826 \\
\hline APTT (seconds) & 46.6 & 5.5 & 40.5 & 5.0 & 0.039 \\
\hline
\end{tabular}

APTT, activated partial thromboplastin time; FBS, fasting blood sugar; PT, prothrombin time; SD, standard deviation; WBC, white blood cells. "Independent $t$-test.

second-line therapy for FVIII inhibitors in patients who failed the prednisone adjuvant therapy (Sarah et al., 2016).

\section{CONCLUSION}

The low dose of $1 \mathrm{mg} /$ body weight/day MP as adjuvant therapy in hemophilia A patients with FVIII inhibitors can suppress the synthesis pace of FVIII inhibitors within 6 weeks. Its long-term administration has minimal side effects. Furthermore, it can be a cost-effective adjuvant therapy in limited healthcare settings. Although low-dose MP did not inhibit the FVIII inhibitors synthesis, this adjuvant therapy is recommended for hemophilia A patients who received longterm FVIII concentrates therapy. Further research is needed to investigate the other effective therapeutic dose of MP. Similar 
Table 2. FVIII inhibitors' pretest-posttest mean comparison of the intervention group and control group, FVIII inhibitors' intergroups pretest and posttest mean comparison.

\begin{tabular}{cccccc}
\hline \multirow{2}{*}{ FVIII inhibitors $(\mathbf{n g} / \mathbf{m l})$} & \multicolumn{2}{c}{ Control $(\boldsymbol{n}=\mathbf{5})$} & \multicolumn{2}{c}{ Intervention $(\boldsymbol{n}=\mathbf{6})$} & \multirow{2}{*}{$\boldsymbol{p}$-value } \\
\cline { 2 - 5 } & Mean & SD & Mean & SD & 0.976 \\
Pretest & 19.0 & 5.8 & 19.2 & 4.7 & 0.034 \\
Posttest & 64.4 & 14.7 & 48.7 & & \\
p-value $^{\#}$ & 0.001 & & 0.001 & & \\
\hline
\end{tabular}

FVIII inhibitors, factor VIII inhibitors; SD, standard deviation.

"Independent $t$-test.

"Paired $t$-test.

interventional clinical research with more than 30 hemophilia A patients or different steroidal anti-inflammatory drugs is also needed to support this study result.

\section{ACKNOWLEDGMENT}

The authors are grateful to the internal medicine specialists of Dr. Moewardi General Hospital for providing feedback and technical support.

\section{AUTHOR CONTRIBUTIONS}

All authors made substantial contributions to conception and design, acquisition of data, or analysis and interpretation of data; took part in drafting the article or revising it critically for important intellectual content; agreed to submit to the current journal; gave final approval of the version to be published; and agree to be accountable for all aspects of the work. All the authors are eligible to be an author as per the international committee of medical journal editors (ICMJE) requirements/guidelines.

\section{FUNDING}

There is no funding to report.

\section{CONFLICTS OF INTEREST}

The authors report no financial or any other conflicts of interest in this work.

\section{PUBLISHER'S NOTE}

This journal remains neutral with regard to jurisdictional claims in published institutional affiliation.

\section{REFERENCES}

Astermark J. FVIII inhibitors: pathogenesis and avoidance. Blood, 2015; 125:2045-51.

Baek HJ, Park YS, Yoo KY, Cha JH, Kim YJ, Lee KS. Healthrelated quality of life of moderate and severe haemophilia patients: results of the haemophilia-specific quality of life index in Korea. PLoS One, 2020; 15(9):e0238686.

Cacciotti C, Chan A, Bhatt M. Oral corticosteroid therapy as an adjuvant treatment for acute bleeding in hemophilia patients with high titer inhibitors. J Pediatr Hematol Oncol, 2021; 43(2):e237-9.

Castaman G, Matino D. Hemophilia A and B: molecular and clinical similarities and differences. Haematologica, 2019; 104(9):1702-9.

Delignat S, Russick J, Gangadharan B, Rayes J, Ing M, Voorberg J, Kaveri SV, Lacroix-Desmazes S. Prevention of the anti-factor VIII memory B-cell response by inhibition of bruton tyrosine kinase in experimental hemophilia A. Haematologica, 2019; 104(5):1046-54.

Ebrahimi L, Kheirandish M, Foroughi M. The effect of methylprednisolone treatment on fibrinolysis, the coagulation system, and blood loss in cardiac surgery. Turk J Med Sci, 2016; 46(6):1645-4.
Kadhim KAR, Al-Lami FH, Baldawi KH. Epidemiological profile of hemophilia in Baghdad-Iraq. Inquiry, 2019; 56(20):1-8.

Khalilian S, Motovali-Bashi M, Rezaie H. Factor VIII: perspectives on immunogenicity and tolerogenic strategies for hemophilia a patients. Int J Mol Cell Med, 2020; 9:33-49.

Machin N, Ragni M V, Smith KJ. Gene therapy in hemophilia A: a cost-effectiveness analysis. Blood Adv, 2018; 2(14):1792-8.

Meeks SL, Batsuli G. Hemophilia and inhibitors: current treatment options and potential new therapeutic approaches. Hematol Am Soc Hematol Educ Program, 2016; 2016(1):657-62.

Permana D, Barliana M, Hamijoyo L. Dosage and duration of methylprednisolone therapy affect the occurrence of cushing habitus in patients with systemic lupus erythematosus. J Pharm Bioallied Sci, 2019; 11(8):S628-34.

Repessé Y, Peyron I, Dimitrov JD, Dasgupta S, Moshai EF, Costa C, Borel-Derlon A, Guillet B, D'Oiron R, Aouba A, Rothschild C, Oldenburg J, Pavlova A, Kaveri SV, Lacroix-Desmazes S. Development of inhibitory antibodies to therapeutic factor VIII in severe hemophilia A is associated with microsatellite polymorphisms in the HMOX1 promoter. Haematologica, 2013; 98(10):1650-5.

Santagostino E, Young G, Carcao M, Mannucci PM, Halimeh S, Austin S. A contemporary look at FVIII inhibitor development: still a great influence on the evolution of hemophilia therapies. Expert Rev Hematol, 2018; 11:87-97.

Sarah L, Prantik D, Gary B. Systemic therapy in acquired haemophilia — a single institute experience. Ulster Med J, 2016; 85(3):187-92.

Tieu P, Chan A, Matino D. Molecular mechanisms of inhibitor development in hemophilia. Mediterr J Hematol Infect Dis, 2020; 12:e2020001.

Walsh CE, Jiménez-Yuste V, Auerswald G, Grancha S. The burden of inhibitors in haemophilia patients. Thromb Haemost, 2016; 116(S $01):$ S10-7.

Witmer C, Young G. Factor VIII inhibitors in hemophilia A: rationale and latest evidence. Ther Adv Hematol, 2013; 4(1):59-72.

Yamanouchi J, Tokumoto D, Ikeda Y, Maruta M, Kaneko M, Hato T, Yasukawa M. Development of an fviii inhibitor in a mild hemophilia patient with a phe595cys mutation. Intern Med, 2018; 57(21):3179-82.

Yang R, Xiong $\mathrm{Y}$, Ke $\mathrm{H}$, Chen $\mathrm{T}$, Gao $\mathrm{S}$. The role of methylprednisolone on preventing disease progression for hospitalized patients with severe COVID-19. Eur J Clin Invest, 2020; 50(11):e13412.

How to cite this article:

Marwanta S, Soetrisno S, Purwanto B, Wasita B, Ardyanto TD, Muhammad F, Pamungkasari EP, Indarto D, Fauzi ER. The effects of low-dose methylprednisolone as adjuvant therapy for hemophilia A patients with factor VIII inhibitors. J Appl Pharm Sci, 2021; 11(12):196-199. 